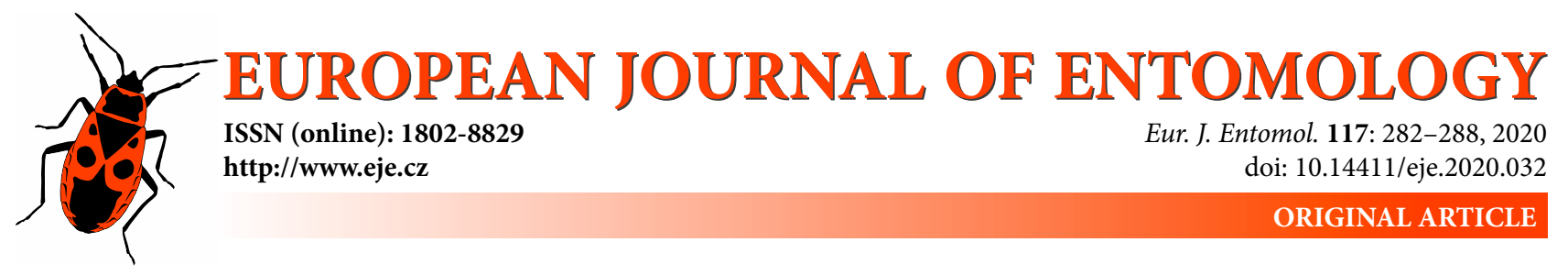

\title{
Distribution of 18S rDNA clusters in Central European harvestmen of the suborder Eupnoi (Arachnida: Opiliones)
}

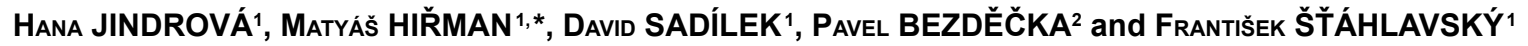 \\ ${ }^{1}$ Charles University, Faculty of Science, Department of Zoology, Viničná 7, CZ-12844 Praha, Czech \\ Republic; e-mails: svojanovska.hanka@seznam.cz, hirmanm@natur.cuni.cz, david.sadilek@natur.cuni.cz, \\ frantisek.stahlavsky@natur.cuni.cz \\ ${ }^{2}$ Museum of the Highlands Jihlava, Masarykovo náměstí 55, CZ-58601 Jihlava, Czech Republic; \\ e-mail: bezdecka@muzeum.ji.cz
}

Key words. Opiliones, Sclerosomatidae, Phalangiidae, karyotype, FISH, NORs, meiosis, 18S rDNA

\begin{abstract}
DNA clusters are an important cytogenetic marker for studying karyotype evolution and chromosomal changes. The variability of this cytogenetic characteristic is, however, still almost unknown in the karyotypes of the entire class Arachnida (Arthropoda: Chelicerata). This situation is particularly evident in harvestmen (Arachnida: Opiliones), with 97 species studied cytogenetically, for which there is information on the number and position of rDNA clusters for only 13. Moreover, previous studies indicate that the number of rDNA loci is highly variable in the species analysed, ranging from one to five pairs of rDNA clusters. Based on this fragmentary information, which is for rare species mainly from the limits of the distribution of their families, it is still not possible to reconstruct the ancestral state for this important cytogenetic feature in this order. Building upon recent research in Central Europe, we analysed the number and position of $18 \mathrm{~S}$ rDNA in 13 species belonging to the suborder Eupnoi. This revealed that their karyotypes were variable in terms of the diploid number $(2 n=16-36)$ and number of $18 S$ rDNA clusters (from one to seven pairs). For the first time, an 18S rDNA cluster was detected on B chromosomes in harvestmen. Our study sheds new light on the karyotype evolution and 18S rDNA distribution in harvestmen and provides an improved understanding of the ancestral state of karyotypes in the order Opiliones.
\end{abstract}

\section{INTRODUCTION}

The Eupnoi is one of the four suborders of the order Opiliones (Arthropoda: Arachnida), which together with the suborders Dyspnoi, Cyphophthalmi and Laniatores, constitute the third-largest order of the class Arachnida (e.g. Giribet \& Kury, 2007; Pinto-da-Rocha et al., 2007). Despite their high diversity (6500 described species: Kury, 2017), only 97 species of harvestman have been cytogenetically analysed (Tsurusaki et al., 2020). Despite this paucity of data, some harvestmen are very variable in their basic cytogenetic characteristics, such as chromosome number $(2 \mathrm{n}=10-109)$, degree of differentiation between the sex chromosomes, the presence of $\mathrm{B}$ chromosomes and possible polyploidy (see Tsurusaki \& Cokendolpher, 1990; Tsurusaki, 2007).

The most general ancestral state indicate morphologically undifferentiated sex chromosomes in harvestmen (e.g. Tsurusaki, 2007; Svojanovská et al., 2016). The XY sex chromosome system is reported only in the harvestman Sabacon makinoi Suzuki, 1949 (Dyspnoi: Sabaconidae) (Tsurusaki, 1989) and 13 species of the Sclerosomatidae
(Eupnoi) (see Tsurusaki et al., 2020). The exception, in the whole Class Arachnida, is one population of Mitopus morio (Fabricius, 1799) (Eupnoi: Phalangiidae), which potentially has a WZ system (Tsurusaki \& Cokendolpher, 1990). However, the differences in chromosome length in some bivalents and their interpretation as sex chromosomes, may reflect the heterozygous nature of the nucleolus organiser regions (NORs) (Št'áhlavský et al., 2018). The NORs include the major ribosomal RNA (45S rRNA: i.e. $18 \mathrm{~S}, 5.8 \mathrm{~S}$, and $28 \mathrm{~S}$ rRNA) gene clusters, which are variable in harvestmen. Moreover, there is little data on this cytogenetic marker in this group of arachnids. This is the reason why it is currently not possible to specify precisely an ancestral state for this order. Silver staining has identified only one NOR, in Psathyropus tenuipes (L. Koch, 1878) (Eupnoi: Sclerosomatidae) (Gorlov \& Tsurusaki, 2000) and Dyscocyrtus pectinifemur (Mello-Leitão, 1937) (Laniatores: Gonyleptidae) (Schneider et al., 2008) and one pair of NORs, in Goniosoma spelaeum (Mello-Leitão, 1932) (Laniatores: Gonyleptidae) (Oliveira et al., 2006). However, fluorescence in-situ hybridisation (FISH), using

\footnotetext{
* Corresponding author; e-mail: hirmanm@natur.cuni.cz
} 
an 18S rDNA probe, frequently reveals one or two pairs of $18 \mathrm{~S}$ rDNA clusters in different families of the suborder Cyphophthalmi and Parapurcellia amatola de Bivort \& Giribet, 2010 (Cyphophthalmi: Pettalidae), with the number of such clusters sometimes being up to five pairs (Svojanovská et al., 2016). An increase in the number of $18 \mathrm{~S}$ rDNA clusters from two to seven and the variability of the heterozygosity in the number and size of such clusters, have also been identified in five species of phalangiid from South Africa (Št'áhlavský et al., 2018). All previously analysed species have considerably limited dispersal abilities, which has resulted in distinct genetic differentiation (e.g. Giribet et al., 2016) and most likely in rapid changes in the distribution of NORs. FISH, using the 5S rDNA probe, revealed that in the harvestman Psathyropus tenuipes L. Koch, 1878 (Eupnoi: Sclerosomatidae) there is only one pair of this minor cluster of the rRNA gene (Watanabe et al., 2009). However, the position of this 5S rRNA gene cluster evolved independently of that of the major rRNA gene clusters (see Sochorová et al., 2018) and, therefore, this characteristic cannot help us understand the evolutionary dynamics of NORs in harvestmen. This is the reasons why we are focusing on the distribution of $18 \mathrm{~S}$ rDNA in phalangiids in Central Europe in the present study. Species from this area are generally widely distributed and gene flow in these taxa is usually not limited, unlike in the previously analysed groups. The objective of this analysis was to better identify the ancestral state of the NORs and the main evolutionary changes in this cytogenetic marker in this suborder.

\section{MATERIALS AND METHODS}

\section{Material}

We analysed 13 species belonging to the families Phalangiidae and Sclerosomatidae from different localities in Central Europe (Table S1). The harvestmen were collected individually and transported alive to the laboratory for subsequent cytogenetic analyses. Analysed specimens are deposited in the public collection of the Faculty of Science, Charles University in Prague.

\section{Chromosome preparations and karyotype evaluation}

We used the "plate-spreading" technique (Traut, 1976) for chromosome preparations according to Št’áhlavský \& Král (2004). During this procedure, dissected gonads were incubated in a hypotonic solution of $0.075 \mathrm{M} \mathrm{KCl}$ for 20 min then fixed in methanol : glacial acetic acid $(3: 1)$ for at least $20 \mathrm{~min}$. Finally, the tissue was dissolved in a drop of $60 \%$ acetic acid on a microscope slide and spread on the surface of the microscope slide and left to evaporate. The chromosome preparations were stained with 5\% Giemsa solution in Sörensen phosphate buffer for 15 min. The chromosomes were photographed using an ORCA-AG monochromatic camera (Hamamatsu Photonics Europe, Herrsching, DE) attached to an Olympus IX81 microscope. The karyotypes were described based on at least five sister metaphase II (the morphology of the chromosomes is unclear in the mitotic metaphases) nuclei using the software ImageJ 1.45r (Schneider et al., 2012) with the plugin Levan (Sakamoto \& Zacaro, 2009).

\section{FISH detection of 18S rDNA}

The probe for $18 \mathrm{~S}$ rDNA was prepared according to Št'áhlavský et al. (2018) and labelled with biotin-14-dUTP using the Nick Translation Kit (Abbott Molecular, Chicago, Illinois, USA). The overall hybridisation procedure followed the protocol described by Fuková et al. (2005) including the initial treatment with RNase A $(200 \mu \mathrm{g} / \mathrm{ml}$ in $2 \times \mathrm{SSC})$ for one hour $\left(37^{\circ} \mathrm{C}\right)$. Denaturation of chromosomes was done at $68^{\circ} \mathrm{C}$ for $3 \mathrm{~min}$ and $30 \mathrm{~s}$ in $70 \%$ formamide in $2 \times \mathrm{SSC}$. Then a probe mixture $(20 \mathrm{ng}$ of the probe, $25 \mu \mathrm{g}$ of salmon sperm DNA, $10 \mu \mathrm{l}$ of $50 \%$ formamide, $20 \%$ dextran sulphate in $2 \times \mathrm{SSC}$ ) was put on each slide and allowed to hybridize overnight $\left(37^{\circ} \mathrm{C}\right)$. Then the probe was detected using Cy3-conjugated streptavidin, followed by the application of biotinylated antistreptavidin and another dose of $\mathrm{Cy} 3$-conjugated streptavidin. Chromosomes were counterstained with DAPI (FluoroshieldTM; Sigma-Aldrich, St. Louis, Missouri, USA) and observed under an Olympus IX81 microscope equipped with an ORCA-AG monochromatic charge-coupled device camera (Hamamatsu). The images were pseudo coloured and superimposed using Cell^R software (Olympus Soft Imaging Solutions $\mathrm{GmbH})$.

\section{RESULTS}

\section{Family Phalangiidae}

We analysed seven species belonging to following genera: Egaenus, Lacinius, Mitopus, Oligolophus, Opilio,

Table 1. Summary of the cytogenetic characteristics of the Eupnoi analysed. a - acrocentric chromosomes, B - B chromosomes, c - centromeric region, $\mathrm{m}$ - metacentric chromosomes, $\mathrm{sm}$ - submetacentric chromosomes, $\mathrm{s}$ - subterminal region, $\mathrm{t}-\mathrm{terminal}$ region, ? - unclear chromosome pairs with $18 \mathrm{~S}$ rDNA cluster.

\begin{tabular}{|c|c|c|c|c|c|}
\hline Family / Species & $2 n$ & $\begin{array}{c}\text { Karyotype } \\
\text { formula }\end{array}$ & $\begin{array}{c}\text { Length of the haploid } \\
\text { set }(\%)\end{array}$ & $\begin{array}{c}\text { Number of } 18 S \\
\text { rDNA clusters }\end{array}$ & $\begin{array}{c}\text { Position of 18S rDNA } \\
\text { pair }+ \text { morph / pos }\end{array}$ \\
\hline \multicolumn{6}{|l|}{ Phalangiidae } \\
\hline Oligolophus tridens & 16 & $12 \mathrm{~m}, 4 \mathrm{sm}$ & $9.66-4.17$ & 1 pair & 7. pair sm / t \\
\hline Egaenus convexus & 24 & $10 \mathrm{~m}, 14 \mathrm{sm}$ & $8.96-4.04$ & 1 pair & 1. pair $\mathrm{m} / \mathrm{c}$ \\
\hline Opilio canestrinii & 24 & $18 \mathrm{~m}, 6 \mathrm{sm}$ & $12.70-5.16$ & 1 pair & 1. pair $\mathrm{m} / \mathrm{s}$ \\
\hline Phalangium opilio & 24 & $18 \mathrm{~m}, 6 \mathrm{sm}$ & $10.90-4.94$ & 1 pair & 3. pair $\mathrm{m} / \mathrm{c}$ \\
\hline Lacinius epiphiatus & 30 & $24 \mathrm{~m}, 6 \mathrm{sm}$ & $10.86-4.92$ & 5 pairs & 8.sm, 9.sm, 12.m, 13.m, 14.sm pair / t \\
\hline Mitopus morio & 32 & $22 \mathrm{~m}, 10 \mathrm{sm}$ & $8.88-3.8$ & 7 pairs & $? / \mathrm{t}$ \\
\hline Rilaena triangularis & 36 & $30 \mathrm{~m}, 6 \mathrm{sm}$ & $9.00-3.8$ & 4 pairs & $? / \mathrm{s}-\mathrm{t}$ \\
\hline \multicolumn{6}{|l|}{ Sclerosomatidae } \\
\hline Leiobunum blackwalli & 20 & $16 \mathrm{~m}, 4 \mathrm{sm}$ & $13.10-6.90$ & 1 pair & 1. pair $\mathrm{m} / \mathrm{t}$ \\
\hline Leiobunum rotundum & $20+0-3 B$ & $14 \mathrm{~m}, 6 \mathrm{sm}, 0-3 \mathrm{Ba}$ & $11.56-8.56$ & 1 pair + 0-3B & 2. pair $\mathrm{m} / \mathrm{t}$ \\
\hline Leiobunum limbatum & 22 & $14 \mathrm{~m}, 8 \mathrm{sm}$ & $11.11-6.91$ & 1 pair & 3. pair $\mathrm{m} / \mathrm{t}$ \\
\hline Leiobunum rupestre & 22 & $22 m$ & $13.68-6.64$ & 1 pair & 3. pair $\mathrm{m} / \mathrm{t}$ \\
\hline Leiobunum gracile & 22 & $14 \mathrm{~m}, 8 \mathrm{sm}$ & $12.75-7.02$ & 1 pair & 4. pair $\mathrm{m} / \mathrm{t}$ \\
\hline Nelima semproni & 24 & $18 \mathrm{~m}, 6 \mathrm{sm}$ & $10.77-6.51$ & 2 pairs & 3. and 5. pair $\mathrm{m} / \mathrm{t}$ \\
\hline
\end{tabular}



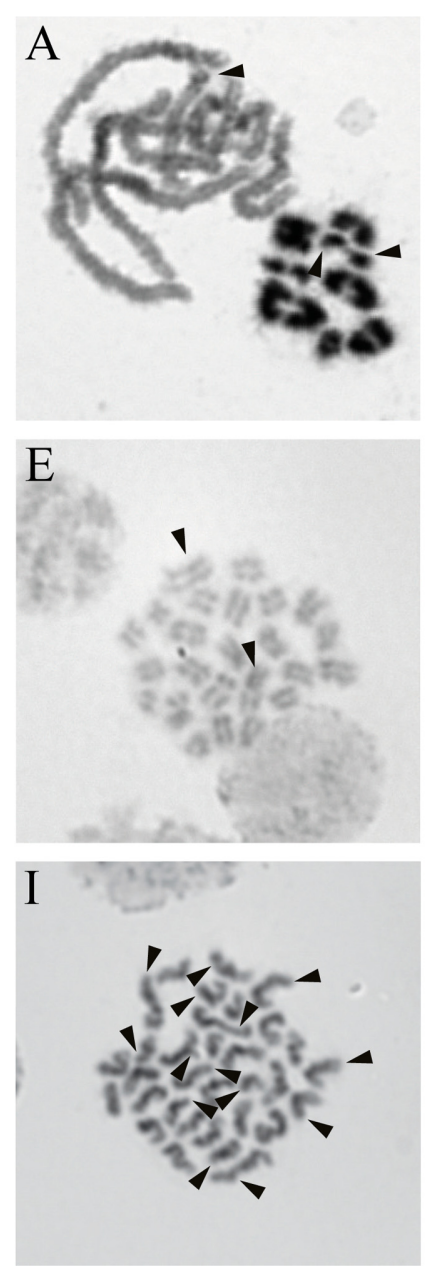
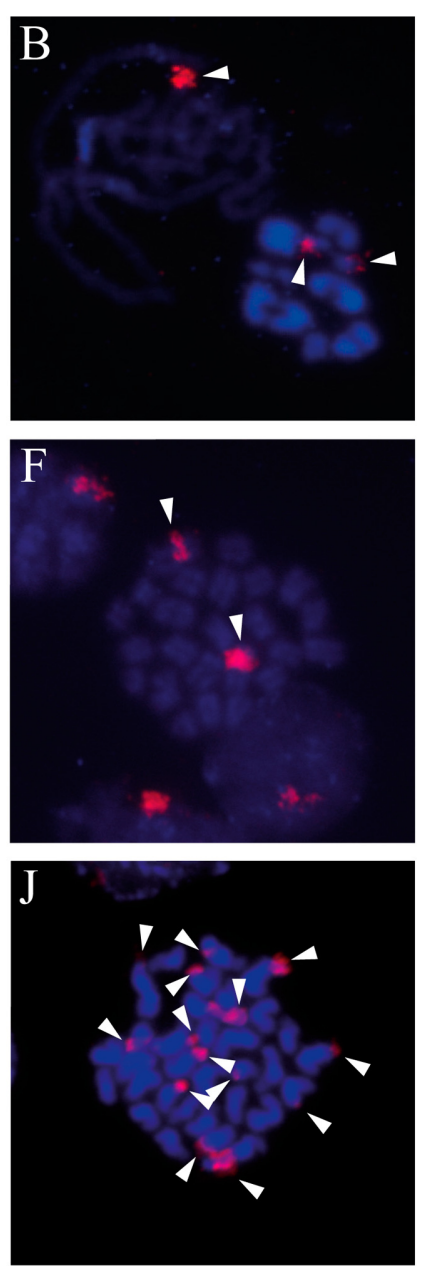

$\mathrm{C}$
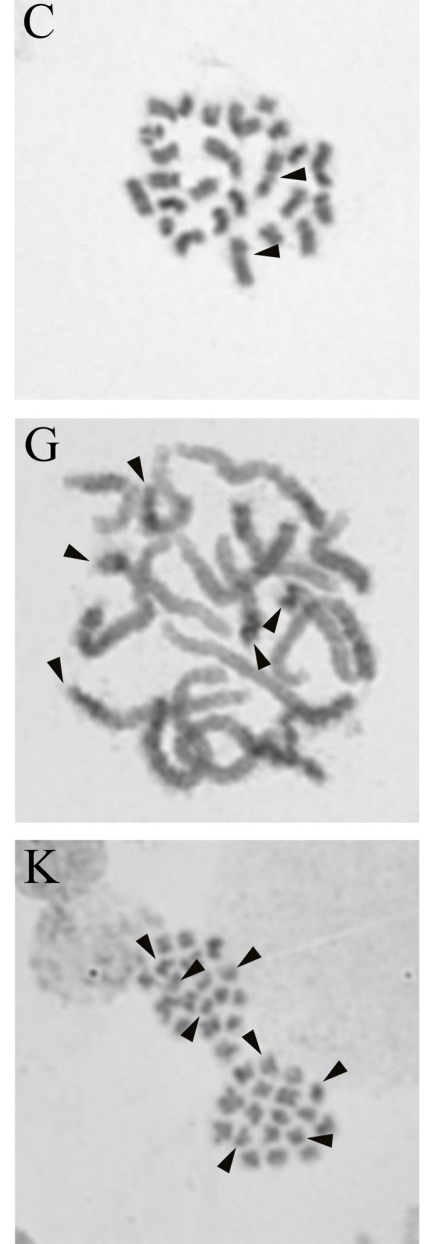
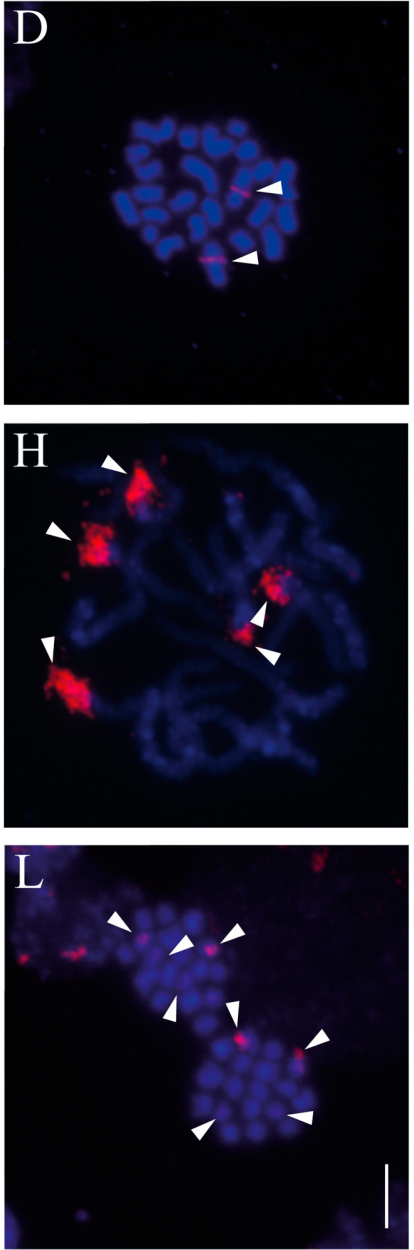

Fig. 1. The chromosomes of the family Phalangiidae. The chromosomes are counterstained with Giemsa (A, C, E, G, I, K) and the same nuclei after FISH with DAPI (blue) (B, D, F, H, J, L). Oligolophus tridens $(2 \mathrm{n}=16)$ : A, B - pachytene and diakinesis; Egaenus convexus $(2 \mathrm{n}$ $=24)$ : C, D - mitotic metaphase; Opilio canestrinii $(2 n=24)$ : $E, F-$ mitotic metaphase; Lacinius ephipiatus $(2 n=30): G, H-$ late pachytene; Mitopus morio $(2 \mathrm{n}=32)$ : I, J - mitotic metaphase; Rilaena triangularis $(2 \mathrm{n}=36): \mathrm{K}, \mathrm{L}-\mathrm{two}$ sister cells of metaphase II. Arrowheads indicate the position of $18 \mathrm{~S}$ rDNA clusters (red signals). Bar $=5 \mu \mathrm{m}$.

Phalangium and Rilaena. Their karyotype diploid numbers range from $2 n=16$ to $2 n=36$ and consist of mainly biarmed chromosomes that gradually decrease in length and the number and positions of $18 \mathrm{~S}$ rDNA differ considerably (Table 1).

The lowest number of chromosomes $(2 \mathrm{n}=16)$ occurred in the species Oligolophus tridens (C.L. Koch, 1836) (Fig. 1A). In this species, we detected one pair of $18 \mathrm{~S}$ rDNA clusters at the ends of the seventh pair of chromosomes (Fig. 1B). The karyotypes of Egaenus convexus (C.L. Koch, 1835) (Fig. 1C), Opilio canestrinii (Thorell, 1876) (Fig. 1E) and Phalangium opilio (Linnaeus, 1761) (Fig. S1A) consisted of $2 n=24$ with one pair of 18 S rDNA clusters in the males of these species. These clusters were close to the centromere of the first (E. convexus, Fig. 1D) and third (P. opilio, Fig. S1B) pair of chromosomes and at a subterminal position on the first pair of chromosomes $(O$. canestrinii, Fig. 1F). Several 18S rDNA gene clusters occurred in the last three species analysed. Karyotype of Lacinius epiphiatus (C.L. Koch, 1835) $(2 \mathrm{n}=30)$ included five pairs of these clusters at terminal positions on the eighth, ninth, twelfth, thirteenth and fourteenth pair of chromo- somes (Fig. 1G-H). In Mitopus morio (Fabricius, 1799) $(2 n=32)$ there were seven pairs of clusters of $18 \mathrm{~S}$ rDNA also always at a terminal position (Fig. 1I-J). Karyotype of the species Rilaena triangularis (Herbst, 1799) $(2 n=36)$ included four pairs of $18 \mathrm{~S}$ rDNA clusters at subterminal or terminal positions (Fig. 1K-L). For the last two mentioned species it was not possible to specify the chromosome pairs bearing $18 \mathrm{~S}$ rDNA clusters in their karyotype.

\section{Family Sclerosomatidae}

We analysed six species belonging to the genus Leiobunum and one to the genus Nelima. The karyotypes $(2 \mathrm{n}=$ 20-24) and the number and positions of 18S rDNA differ slightly between genera. In all species biarmed chromosomes predominate and gradually decrease in size (Table 1).

In one male of $L$. blackwalli (Meade, 1861), we identified $2 \mathrm{n}=20$ (Fig. 2A) same as in the species L. rotundum (Latreille, 1798). However, in one male of L. rotundum from České Budějovice we identified a variable $2 \mathrm{n}$ caused by the presence of 0-3 B chromosomes (Fig. 2C). Three other species, L. limbatum L. Koch, 1861 (Fig. 2E), L. rupestre (Herbst, 1799) (Fig. 2G) and L. gracile Thorell, 1876 (Fig. 

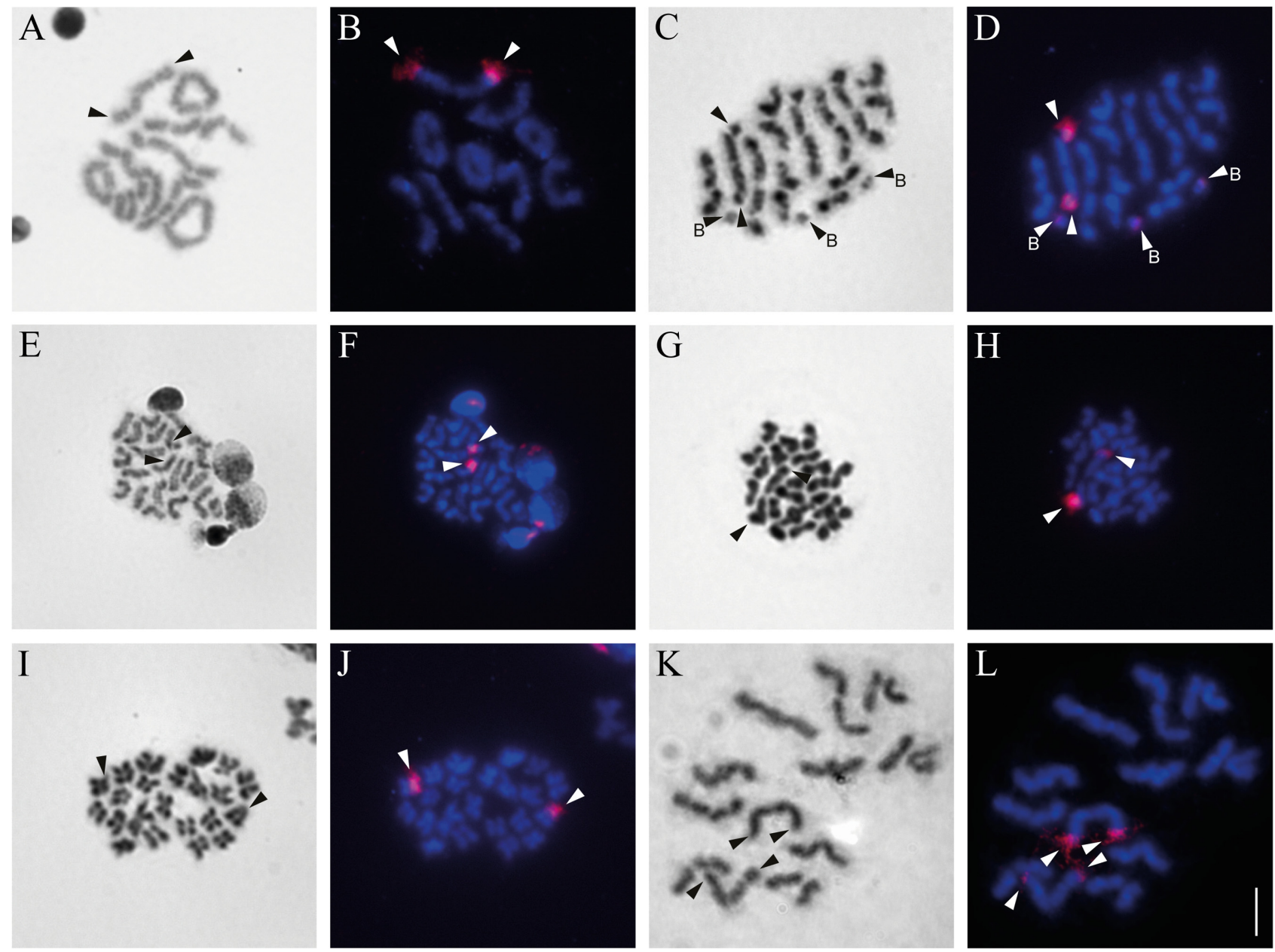

Fig. 2. The chromosomes of the family Sclerosomatidae. The chromosomes are counterstained with Giemsa $(A, C, E, G, I, K)$ and the same nuclei after FISH with DAPI (blue) $(B, D, F, H, J, L)$. Leiobunum blakwalli $(2 n=20): A, B-$ diplotene; Leiobunum rotundum $(2 n=20+$ $3 B)$ : C, D - late metaphase I; Leiobunum limbatum $(2 n=22): E, F-$ mitotic metaphase; Leiobunum rupestre $(2 n=22): G, H-$ diakinesis; Leiobunum gracile $(2 n=22)$ : I, J - two sister cells of metaphase II; Nelima semproni $(2 n=24): K, L$ - diplotene. Arrowheads indicate the position of $18 \mathrm{~S}$ rDNA clusters (red signals) and the position of B chromosomes by arrowheads with "B". Bar $=5 \mu \mathrm{m}$.

2I) had $2 \mathrm{n}=22$. The number and position of $18 \mathrm{~S}$ rDNA is very consistent in all of the five species of Leiobunum analysed. We identified only one pair of $18 \mathrm{~S}$ rDNA signals always at a terminal position and mostly on one of the first three chromosome pairs, see Table 1 (Fig. 2B, D, F, H, J). Interestingly, we identified an $18 \mathrm{~S}$ rDNA cluster on all three B chromosomes in the species Leiobunum rotundum (Fig. 2D). Compared to that in the species Nelima semproni (Szalay, 1951) $(2 \mathrm{n}=24)($ Fig. $2 \mathrm{~K})$ two pairs of $18 \mathrm{~S}$ rDNA clusters were detected by FISH on terminal parts of the third and fifth chromosome pair (Fig. 2L).

\section{DISCUSSION}

NORs are one of the most commonly observed markers in animal karyotypes. Previously, this region was identified mainly by silver staining, which can underestimate the number of NORs (Miller et al., 1976). FISH is currently a better and more frequently used tool for mapping the major ribosomal RNA (i.e. $45 \mathrm{~S}: 18 \mathrm{~S}, 5.8 \mathrm{~S}$ and $28 \mathrm{~S}$ ) gene clusters (e.g. Nguyen et al., 2010; Mattos et al., 2014; Štundlová et al., 2019). Recent reviews of the literature and an online database indicate that, despite the wide range in numbers of $45 \mathrm{~S}$ rDNA loci (from one to 54 loci/2C) in animals, about $60 \%$ of the karyotypes have only a single $45 \mathrm{~S}$ locus (Sochorová et al., 2018) and 45S rDNA is most frequently distally located (Sochorová et al., 2018). These characteristics correspond with the predicted ancestral state of $45 \mathrm{~S}$ rDNA in arachnids in general (Forman et al., 2013) and harvestmen in particular (Svojanovská et al., 2016). Only a few species of harvestmen, from only two suborders, have been analysed, the Cyphophthalmi (Svojanovská et al., 2016; Hiřman et al., 2018) and the Eupnoi (Št'áhlavský et al., 2018). These studies reveal numbers of rDNA clusters that differ from the predicted ancestral state; for example, Parapurcellia amatola (Cyphophthalmi) has 10 signals of 18S rDNA (Svojanovská et al., 2016) and Rhampsinitus leighi (Pocock, 1903) (Eupnoi) has seven (Štáhlavský et al., 2018). However, Miopsalis sp. (Styllocelidae), which has a basal position in the harvestmen phylogeny, with a diploid number $2 n=30$, has one pair of $18 \mathrm{~S}$ rDNA clusters in a terminal position and no acrocentric pairs of chromosomes in the karyotype (Svojanovská et al., 2016).

Our study has increased the knowledge based on the number and position of rDNA clusters in the Suborder 
Eupnoi (Št'áhlavský et al., 2018). We detected one pair of $18 \mathrm{~S}$ rDNA clusters in most of the species analysed, whilst showing that there is some difference in localisation on chromosome; for example, pericentromeric in Egaenus convexus, subterminal in Opilio canestrinii and terminal in Rilaena triangularis (all family Phalangiidae). Also, we detected 18S rDNA multiplication in three species of the family Phalangiidae: Lacinius epiphiatus $(2 \mathrm{n}=30$, five pairs), Mitopus morio $(2 \mathrm{n}=32$, seven pairs $)$ and Rilaena triangularis $(2 \mathrm{n}=36$, four pairs), and in one species of the family Sclerosomatidae: Nelima semproni $(2 \mathrm{n}=24$, two pairs). These results indicate that, despite the recent finding of high variability in $18 \mathrm{~S}$ rDNA clusters in species from South Africa (Št'áhlavský et al., 2018), 18S rDNA may be conserved in some species of the Suborder Eupnoi. High numbers of $18 \mathrm{~S}$ rDNA clusters are frequently recorded in specimens inhabiting regions with extreme conditions and may thus represent an adaptation to such conditions, as has previously been postulated for other taxa, such as fish (Symonová et al., 2013; Sember et al., 2015). However, we need more data to confirm this in harvestmen. B chromosomes are already reported in some species of the Suborder Eupnoi (Tsurusaki, 2007; Watanabe et al., 2009), but here, for the first time, 18S rDNA was detected on B chromosomes in harvestmen, specifically in the species Leiobunum rotundum. B chromosomes carrying rDNA (active or inactive) have already been detected in vertebrates, such as rats (Stitou et al., 2004) and fish (Baroni et al., 2009; Poletto et al., 2010), and also in invertebrates, such as the grasshopper Dichroplus pratensis Bruner, 1900 (Bidau et al., 2004). Further investigation is necessary to obtain a better understanding of the function of rDNA on B chromosomes in harvestmen.

ACKNOWLEDGEMENTS. We are grateful to P. Dolejš, A. Jelínek, P. Just, and D. Ř́hová for providing some material. The present study was supported by grants from the Ministry of Education, Youth and Sports of the Czech Republic (No. SVV 260571/2020) and we also acknowledge the support provided by Grant Agency of Charles University in Prague (GAUK) no. 582119. Microscopy was performed in the Laboratory of Confocal and Fluorescence Microscopy, co-financed by the European Regional Development Fund and the state budget of the Czech Republic. Project no. CZ.1.05/4.1.00/16.0347 and CZ.2.16/3.1.00/21515.

\section{REFERENCES}

Baroni S., Lopes C.E. \& de Almeida-Toledo L.F. 2009: Cytogenetic characterization of Metynnis maculatus (Teleostei; Characiformes): the description in Serrasalminae of a small B chromosome bearing inactive NOR-like sequences. - Caryologia 62: $95-101$.

Bidau C.J., Rosato M. \& Marti D.A. 2004: FISH detection of ribosomal cistrons and assortment-distortion for $\mathrm{X}$ and $\mathrm{B}$ chromosomes in Dichroplus pratensis (Acrididae). - Cytogenet. Genome Res. 106: 295-301.

Forman M., Nguyen P., Hula V. \& Král J. 2013: Sex chromosome pairing and extensive NOR polymorphism in Wadicosa fidelis (Araneae: Lycosidae). - Cytogenet. Genome Res. 141: 43-49.

Fukoví I., Nguyen P. \& Marec F. 2005: Codling moth cytogenetics: karyotype, chromosomal location of rDNA, and mo- lecular differentiation of sex chromosomes. - Genome 48: 1083-1092.

Giribet G. \& KuRY A.B. 2007: Phylogeny and biogeography. In Pinto-da-Rocha R., Machado G. \& Giribet G. (eds): Harvestmen: The Biology of Opiliones. Harvard University Press, Cambridge, MA, pp. 62-87.

Giribet G., Boyer S.L., Baker C.M., Fernández R., Sharma P.P., DE Bivort B.L. \& GRISwold C.E. 2016: A molecular phylogeny of the temperate Gondwanan family Pettalidae (Arachnida, Opiliones, Cyphophthalmi) and the limits of taxonomic sampling. - Zool. J. Linn. Soc. 178: 523-545.

Gorlov I.P. \& TsURASAKI N. 2000: Morphology and meiotic/mitotic behavior of B chromosomes in a Japanese harvestman, Metagagrella tenuipes (Arachnida: Opiliones): No evidence for B accumulation mechanisms. - Zool. Sci. 17: 349-355.

HiŘMan M., KотYK M., KotYKová Z.V. \& ŠŤÁhlavsKÝ F. 2018: First cytogenetic study of a member of the harvestman family Neogoveidae (Opiliones: Cyphophthalmi: Sternophthalmi) from Cameroon with a description of a new species Parogovia parasironoides sp. nov. — Ann. Zool. (Warsaw) 68: 867-877.

KURY A.B. 2017: Classification of Opiliones. URL: http://www. museunacional.ufrj.br/mndi/Aracnologia/opiliones.html.

Mattos V.F., Carvalho L.S., Cella D.M. \& Schneider M.C. 2014: Location of 45S ribosomal genes in mitotic and meiotic chromosomes of buthid scorpions. - Zool. Sci. 31: 603-608.

Miller D.A., Dew V., Tantravahi R. \& Miller O. 1976: Supression of human nucleolar organizer activity in mouse human somatic hybrid cells. - Exp. Cell Res. 101: 235-243.

Nguyen P., Sahara K., Yoshido A. \& Marec F. 2010: Evolutionary dynamics of rDNA clusters on chromosomes of moths and butterflies (Lepidoptera). — Genetica 138: 343-354.

Oliveira R.M., Zacaro A.A., Gnaspini P. \& Cella D.M. 2006: Cytogenetics of three Brazilian Goniosoma species: a new record for diploid number in Laniatores (Opiliones, Gonyleptidae, Goniosomatinae). - J. Arachnol. 34: 435-443.

Pinto-da-Rocha R., Machado G. \& Giribet G. (eds) 2007: Harvestmen: The Biology of Opiliones. Harvard University Press, Cambridge, MA, 597 pp.

Poletto A.B., Ferreira I.A. \& Martins C. 2010: The B chromosomes of the African cichlid fish Haplochromis obliquidens harbour 18S rRNA gene copies. - BMC Genet. 11: 1, 8 pp.

SAKAmoto Y. \& ZACARO A.A. 2009: LEVAN, an ImageJ Plugin for Morphological Cytogenetic Analysis of Mitotic and Meiotic Chromosomes. URL: http://rsbweb.nih.gov/ij/plugins/levan/ levan.html.

Schneider M.C., Zacaro A.A., Pinto-Da-Rocha R., Candido D.M. \& Cella D.M. 2008: Conventional and ultrastructural analyses of the chromosomes of Discocyrtus pectinifemur (Opiliones, Laniatores, Gonyleptidae). - J. Zool. Syst. Evol. Res. 47: 203-207.

SchNeIDER C.A., Rasband W.S. \& Eliceiri K.W. 2012: NIH Image to ImageJ: 25 years of image analysis. - Nature Meth. 9: 671675.

Sember A., Bohlen J., Šlechtová V., Altmanová M., Symonová R. \& RÁB P. 2015: Karyotype differentiation in 19 species of river loach fishes (Nemacheilidae, Teleostei): extensive variability associated with rDNA and heterochromatin distribution and its phylogenetic and ecological interpretation. - $B M C$ Evol. Biol. 15: 251, 22 pp.

Sochorová J., Garcia S., Gálvez F., Symonová R. \& Kovařík A. 2018: Evolutionary trends in animal ribosomal DNA loci: introduction to a new online database. - Chromosoma 127 : 141-150. 
ŠŤÁHLAVSKÝ F. \& KRÁL J. 2004: Karyotype analysis and achiasmatic meiosis in pseudoscorpions of the family Chthoniidae (Arachnida: Pseudoscorpiones). - Hereditas 140: 49-60.

ŠŤÁHlavský F., Opatova V., Just P., Lotz L.N. \& Haddad C.R. 2018: Molecular technique reveals high variability of $18 \mathrm{~S}$ rDNA distribution in harvestmen (Opiliones, Phalangiidae) from South Africa. - Comp. Cytogenet. 12: 41-59.

Stitou S., Zurita F., Diaz de la Guardia R., Jimenez R. \& Burgos M. 2004: Transmission analysis of B chromosomes in Rattus rattus from Northern Africa. - Cytogenet. Genome Res. 106 : 344-346.

ŠTundlová J., Šmíd J., NGUYEN P. \& ŠŤÁHLAVSKÝ F. 2019: Cryptic diversity and dynamic chromosome evolution in Alpine scorpions (Euscorpiidae: Euscorpius). - Mol. Phylogenet. Evol. 134: $152-163$.

Svojanovská H., NguYen P., Hiřman M., Tuf I.H., Wahab R.A., HADDAD C.R. \& ŠŤÁHLAVSKÝ F. 2016: Karyotype evolution in harvestmen of the suborder Cyphophthalmi (Opiliones). $-C y$ togenet. Genome Res. 148: 227-236.

Symonová R., Flajšhans M., Sember A., Havelka M., Gela D., KoŘínková T., Rodina M., RÁbová M. \& RÁb P. 2013: Molecular cytogenetics in artificial hybrid and highly polyploid stur- geons: an evolutionary story narrated by repetitive sequences. - Cytogenet. Genome Res. 141: 153-162.

Traut W. 1976: Pachytene mapping in the female silkworm Bombyx mori L. (Lepidoptera). - Chromosoma 58: 275-284.

TsURUSAKI N. 1989: Geographic variation of chromosomes in $\mathrm{Sa}$ bacon makinoi Suzuki (Arachnida, Opiliones, Sabaconidae). - Bull. Biogeogr. Soc. Jap. 44: 111-116.

Tsurusaki N. 2007: Cytogenetics. In Pinto-da-Rocha R., Machdo G. \& Giribet G. (eds): Harvestmen: The Biology of Opiliones. Harvard University Press, Cambridge, MA, pp. 266-279.

TSURUSAKI N. \& COKENDOLPHER J. 1990: Chromosomes of sixteen species of harvestman (Arachnida, Opiliones, Caddidae and Phalangidiidae). - J. Arachnol. 18: 151-166.

Tsurusaki N., Svojanovská H., SchÖEnhofer A. \& ŠŤÁHLAVskÝ F. 2020: The Harvestmen Cytogenetic Database. Vers. 6.5. URL: http://www.arthropodacytogenetics.bio.br/index.html (last accessed 1 Apr. 2020).

Watanabe M., Tsurusaki N. \& Kubota S. 2009: Molecular cytogenetic characterization of 5S rDNA in Psathyropus tenuipes (Arachnida: Opiliones). - Chromosome Sci. 12: 51-53.

Received April 10, 2020; revised and accepted May 25, 2020 Published online June 11, 2020

Supplementary material follows (Table S1, Fig. S1). 
Table S1. Sex, location and date collected for the species included in this study.

\begin{tabular}{|c|c|c|c|c|}
\hline Species & Locality & Date & GPS & Males \\
\hline \multicolumn{5}{|l|}{ Phalangiidae } \\
\hline Egaenus convexus (C.L. Koch, 1835) & Havraníky & 5.5 .2014 & $48.8174 \mathrm{~N}, 15.9824 \mathrm{E}$ & 1 \\
\hline \multirow{4}{*}{ Lacinius ephippiatus (C.L. Koch, 1835) } & Horní Vltavice & 17. 7.2014 & $48.9778 \mathrm{~N}, 13.8076 \mathrm{E}$ & 1 \\
\hline & Horní Vltavice & 17. 7. 2014 & $48.9533 \mathrm{~N}, 13.7720 \mathrm{E}$ & 1 \\
\hline & Zátoň & 18. 7.2014 & $48.9470 \mathrm{~N}, 13.8269 \mathrm{E}$ & 1 \\
\hline & Jamné nad Orlicí & 22. 7.2014 & $50.0534 \mathrm{~N}, 16.6667 \mathrm{E}$ & 1 \\
\hline \multirow{7}{*}{ Mitopus morio (Fabricius, 1799) } & Hřensko & 24. 6. 2012 & $50.8770 \mathrm{~N}, 14.2829 \mathrm{E}$ & 1 \\
\hline & Orličky & 6. 10. 2012 & $50.0481 \mathrm{~N}, 16.6890 \mathrm{E}$ & 1 \\
\hline & Nová Pec: Plešné jezero & 17. 7.2014 & $48.7773 \mathrm{~N}, 13.8679 \mathrm{E}$ & 1 \\
\hline & Nová Pec: Rakouská louka & 17. 7.2014 & $48.7708 \mathrm{~N}, 13.8528 \mathrm{E}$ & 1 \\
\hline & Říčky v Orlických Horách & 7. 10. 2012 & $50.2177 \mathrm{~N}, 16.4633 \mathrm{E}$ & 1 \\
\hline & Říčky v Orlických Horách & 7. 10. 2012 & $50.2306 \mathrm{~N}, 16.4854 \mathrm{E}$ & 1 \\
\hline & Trhová Kamenice & 7. 8. 2014 & $49.8113 \mathrm{~N}, 15.8082 \mathrm{E}$ & 3 \\
\hline \multirow{4}{*}{ Oligolophus tridens (C.L. Koch, 1836) } & Orlík & 20. 10. 2013 & $49.5118 \mathrm{~N}, 14.1500 \mathrm{E}$ & 1 \\
\hline & Přeseka & 19. 10.2013 & $49.0465 \mathrm{~N}, 14.7420 \mathrm{E}$ & 2 \\
\hline & Těptín & 19. 10. 2013 & $49.8870 \mathrm{~N}, 14.5627 \mathrm{E}$ & 2 \\
\hline & Třeboň & 19. 10. 2013 & $48.9855 \mathrm{~N}, 14.8456 \mathrm{E}$ & 1 \\
\hline \multirow{6}{*}{ Opilio canestrinii (Thorell, 1876) } & České Budějovice & 14. 10. 2014 & $48.9638 \mathrm{~N}, 14.4792 \mathrm{E}$ & 1 \\
\hline & Jílové u Prahy & 20. 9.2014 & $49.8992 \mathrm{~N}, 14.4901 \mathrm{E}$ & 1 \\
\hline & Písty & 30. 9. 2014 & $50.1587 \mathrm{~N}, 15.0107 \mathrm{E}$ & 1 \\
\hline & Praha & 21. 10. 2013 & $50.0704 \mathrm{~N}, 14.4215 \mathrm{E}$ & 2 \\
\hline & Praha & 21. 10. 2013 & $50.0649 \mathrm{~N}, 14.4300 \mathrm{E}$ & 1 \\
\hline & Žabonosy & 3. 8.2014 & $50.0336 \mathrm{~N}, 15.0288 \mathrm{E}$ & 2 \\
\hline \multirow{3}{*}{ Phalangium opilio (Linnaeus, 1761) } & České Budějovice & 14. 10. 2014 & $48.9799 \mathrm{~N}, 14.4640 \mathrm{E}$ & 1 \\
\hline & Pardubice & 30. 9. 2013 & $50.0418 \mathrm{~N}, 15.7776 \mathrm{E}$ & 2 \\
\hline & Praha & 21. 10. 2013 & $50.0821 \mathrm{~N}, 14.4701 \mathrm{E}$ & 1 \\
\hline \multirow{3}{*}{ Rilaena triangularis (Herbst, 1799) } & Káraný & 6.5 .2014 & $50.1802 \mathrm{~N}, 14.7595 \mathrm{E}$ & 2 \\
\hline & Milovice & 27. 5. 2014 & $48.8476 \mathrm{~N}, 16.6813 \mathrm{E}$ & 2 \\
\hline & Pavlov & 28. 5. 2014 & $48.8754 \mathrm{~N}, 16.6607 \mathrm{E}$ & 2 \\
\hline \multicolumn{5}{|l|}{ Sclerosomatidae } \\
\hline Leiobunum blackwalli (Meade, 1861) & Veselí nad Lužnicí & 19. 10. 2013 & $49.1505 \mathrm{~N}, 14.6930 \mathrm{E}$ & 1 \\
\hline \multirow{4}{*}{ Leiobunum limbatum L. Koch, 1861} & Pardubice & 30. 9. 2013 & $50.0418 \mathrm{~N}, 15.7776 \mathrm{E}$ & 1 \\
\hline & Praha & 6. 10. 2012 & $50.0719 \mathrm{~N}, 14.4233 \mathrm{E}$ & 1 \\
\hline & Praha & 6. 10. 2012 & $50.0654 \mathrm{~N}, 14.4220 \mathrm{E}$ & 1 \\
\hline & Říčky v Orlických Horách & 7. 10. 2012 & $50.2177 \mathrm{~N}, 15.4633 \mathrm{E}$ & 2 \\
\hline \multirow{3}{*}{ Leiobunum rotundum (Latreille, 1798) } & České Budějovice & 14. 10. 2014 & $48.9512 \mathrm{~N}, 14.4859 \mathrm{E}$ & 2 \\
\hline & Praha & 21. 10. 2013 & $50.0704 \mathrm{~N}, 14.4215 \mathrm{E}$ & 1 \\
\hline & Veselí nad Lužnicí & 19. 10. 2013 & $49.1505 \mathrm{~N}, 14.6930 \mathrm{E}$ & 1 \\
\hline Leiobunum rupestre (Herbst, 1799) & Říčky v Orlických Horách & 6. 10. 2012 & $50.2177 \mathrm{~N}, 15.4633 \mathrm{E}$ & 1 \\
\hline \multirow{2}{*}{ Leiobunum gracile Thorell, 1876} & Křída & 20.10. 2013 & $49.3512 \mathrm{~N}, 14.5114 \mathrm{E}$ & 1 \\
\hline & Říčky v Orlických Horách & 6. 10. 2012 & $50.2177 \mathrm{~N}, 15.4633 \mathrm{E}$ & 1 \\
\hline Nelima semproni (Szalay, 1951) & Veselí nad Lužnicí & 19. 10. 2013 & $49.1505 \mathrm{~N}, 14.6930 \mathrm{E}$ & 3 \\
\hline
\end{tabular}

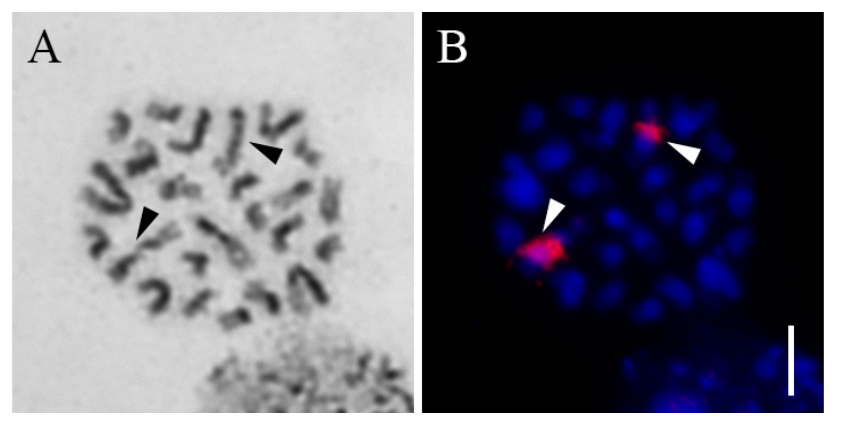

Fig. S1. The chromosomes (mitotic metaphase) of Phalangium opilio $(2 n=24)$ : A - Giemsa staining; $B$ - the same nuclei after FISH with DAPI (blue). Arrowheads indicate the position of $18 \mathrm{~S}$ rDNA clusters (red signals). Bar $=5 \mu \mathrm{m}$. 